Sohannessen, Janne Bondi \& Kristin Hagen (red.) Leksikografi og korpus. En hyllest til Ruth Vatvedt Fjeld, Oslo Studies in Language 11(1), 2020. 31-46. (ISSN 1890-9639 / ISBN 978-82-

http://www.journals.uio.no/osla

\title{
SKÆVHEDER OG LIGESTILLING: \\ I ORDBOGEN, I KORPUS OG I SAMFUNDET
}

\author{
LARS TRAP-JENSEN
}

RESUMÉ

Sproget får vi i arv fra tidligere generationer. Det ændrer sig kun langsomt og er derfor fuldt af vidnesbyrd om ældre tiders opfattelser og syn på verden. Det gælder ikke mindst identitetspolitiske spørgsmål som forholdet mellem kønnene eller synet på de fremmede. I denne artikel ser jeg på hvordan Den Danske Ordbog forsøger at navigere mellem videnskabelighed, deskriptiv forpligtelse og et stigende krav om ligestilling og inklusion når de semantiske beskrivelser revideres og nye ord optages. Redegørelsen omfatter både ordbogen og dens korpusmæssige beskrivelsesgrundlag, og hvor det er relevant, sammenlignes resultaterne med de tilsvarende for norske forhold.

\section{[1] INDLEDNING}

Ordbøgernes definitionspraksis har ændret sig gennem de seneste 100 år. Det hænger givetvis sammen med at beskrivelsesgrundlaget i samme periode har ændret sig. For omkring 100 år siden blev den deskriptive tradition fastlagt $\mathrm{i}$ Norden med nationale opslagsværker som Ordbog over det danske Sprog (ODS) i Danmark og lidt senere Norsk Riksmålsordbok (NRO) i Norge. Sidstnævnte er i dag omarbejdet til en moderne ordbog og udgivet under navnet Det Norske Akademis ordbok (NAOB). Traditionen for deskriptive ordbøger er grundlagt på systematisk og videnskabelig beskrivelse af ordforrådet på empirisk grundlag. Til grund lå dengang store samlinger af sproglige excerpter registreret på kartotekskort, og metoden sikrede at leksikograferne ikke alene konsulterede deres egen sprogfornemmelse, men kunne støtte sig til faktisk forekommende sprogbrug. Alligevel var antallet af excerpter for hver enkelt leksikalsk enhed, forstået som et lemma i én af dets betydninger, af overskuelig størrelse, og for lavfrekvente lemmaers vedkommende undertiden nok så begrænset. Nationalordbøgernes definitionspraksis må forstås på denne baggrund.

Min erfaring med brug af disse ordbøger siger mig at redaktørerne ofte udformede deres definitioner så de i videst muligt omfang dækkede samtlige de belæg som de fandt i excerpterne. En tilsvarende observation er gjort af Nilstun (2012: 130), der ser NRO’s definitioner som tegn på “svak abstraksjon”, hvormed 
menes at definitionerne blev udformet så de var skræddersyede til konkrete enkeltbelæg. Udviklingen af sproglige korpusser op gennem det 20. århundrede medførte blandt andet at det empiriske beskrivelsesgrundlag voksede eksponentielt fra 1960'erne og fremefter. Dermed voksede også antallet af konkrete belæg som redaktørerne fandt for de leksikalske enheder, hvilket umuliggjorde en praksis der omfattede enkeltforekomster i materialet. I stedet er tendensen gået i retning af at beskrive den centrale og typiske sprogbrug. To eksempler kan illustrere forskellen i praksis.

Øjenlaag, et.

1) hos mennesket og visse (højere) dyr: hver af de to tynde, bevægelige hud-folder, -klapper, der udgaar fra henh. øverste og nederste øjenhulerand, og som kan trækkes beskyttende hen over øjeæblets forflade; laag (2.3)

FIGUR 1: ODS: Udsnit af artiklen Øjenlaag

Figur 1 giver et indtryk af hvordan en definition i ODS gerne beskriver detaljeret og med maksimal præcision. Midlerne er indskrænkninger og præciseringer i form af indskudte sætninger eller fraser, forbehold i parenteser og synonymer eller supplerende forklaringer efter komma eller semikolon. Detaljerigdom og udtømmende forklaring har højeste prioritet. Prisen for semantisk præcision er ofte læsbarhed: Forklaringerne kan være syntaktisk komplicerede at afkode, og der kan optræde sjældne eller vanskelige ord der stiller store krav til brugeren (øjenhulerand, forflade). Ordbøgerne henvendte sig snarere til et veluddannet mindretal end til skoleelever og den almene befolkning.

De store korpusser der er vokset frem siden slutningen af 1900-tallet, har efterhånden gjort det umuligt for en enkelt redaktør at overskue det samlede empiriske materiale, og dermed gøres en udtømmende beskrivelse af alle forekomster nærmest umulig. Inden for leksikografien er tendensen derfor dels gået $\mathrm{i}$ retning af mere automatisk præprocessering hvor computere automatisk behandler teksterne og finder karakteristiske mønstre i korpus, dels i at resultatet opdeles i semantiske klynger på grundlag af typisk sprogbrug. Tilsvarende bliver leksikografens opgave i højere grad at beskrive disse centrale og typiske mønstre og i mindre grad at redegøre for grænsetilfælde og perifere forekomster (jf. Trap-Jensen 2014: 53f.).

Figur 2 fra Den Danske Ordbog (DDO) viser at det centrale betydningsindhold beskrives som det første. I eksemplet er der desuden en efterhængt tillægsoplysning der viser at det netop er det typiske: "især" antyder at der er andre muligheder. 
øjenlåg substantiv, intetkøn
bevægelig hudfold der kan dække øjet, især den øverste hudfold

FIGUR 2: DDO: udsnit af artiklen øjenlåg

Det er en helt almindelig definitionsmåde i moderne ordbøger og benyttes også i fX NAOB:

øyelokk substantiv

hudfold over (og under) øyeeplet

FIGUR 3: NAOB: udsnit af artiklen øyelokk

Tanken er at man ved at beskrive det typiske nemt og hurtigt fremkalder en forståelse hos brugeren, og at denne derefter er i stand til at ekstrapolere sin forståelse fra typiske til mere perifere forekomster, i dette tilfælde eksempelvis hvis brugeren har mødt øjenlåg brugt om et dyr.

\section{[2] SAMFUNDET, SPROGET OG ORDBØGERNE}

Imidlertid er også denne praksis i de senere år blevet udfordret af en ny tendens. Ordbøger mødes i stigende omfang med et krav om at sprogbeskrivelsen lever op til ideelle fordringer om ligestilling og sproglig inklusion. Efter nogle gruppers mening kan ordbøgerne ikke nøjes med at beskrive ordene og sproget sådan som de afspejles i et korpus, men bør i højere grad beskrive dem sådan som de burde bruges. Leksikografen kan efter denne forestilling ikke nøjes med at iagttage og beskrive, men har et moralsk ansvar for at handle aktivistisk og rette op på uønskede skævheder i sproget, skævheder som skyldes et efterslæb fra en vildfaren fortid som vi bør lægge bag os (se fx diskussioner heraf i Russell 2012, Nossem 2018 samt Moon 2014 nedenfor).

Leksikografisk er problemstillingen interessant og relevant, for selvom leksikografer ynder at opfatte sig selv som dokumenterende og deskriptive, er leksikografi for det første ikke nogen eksakt videnskab, men rummer mange elementer af subjektivt skøn, for det andet spiller sproget og ordbøgernes beskrivelse af det en vigtig rolle når det gælder normdannelse i samfundet - uanset hvilken opfattelse ordbøgerne har af sig selv. Ifølge Moon (2014) er det beskrivelsen af ikke-denotativ betydning og især det ideologisk ladede ordforråd der volder problemer:

there is a particular dilemma facing lexicographers attempting to deal with contested and ideologically loaded words: to balance a description of what data suggests about meaning with how in a post- 
modern inclusive society, the relevant concept "ought" to be regarded and represented.

(Moon 2014: 89)

Metodisk er det dog vigtigt at skelne mellem hvilke normer der præger samfundet, fx opfattelsen af mænds og kvinders roller og forholdet mellem kønnene, og hvordan normerne afspejles sprogligt, $\mathrm{fx}$ i form af ordforråd og sproglige forbindelser, og endelig det operationaliserede sprog i form af tekster som kan studeres empirisk af leksikografer og føre til beskrivelser i eksempelvis ordbøger. Man må følgelig skelne mellem 1) skævheder i samfundet, 2) skævheder i sproget, 3) skævheder i korpus og 4) skævhed i ordbøgerne. Der er naturligvis en vis sammenhæng mellem dem, idet samfundsnormer sætter sig sproglige spor som kan beskrives i ordbøger på grundlag af korpustekster, men forholdet mellem dem er ikke nødvendigvis enkelt og omsætningen ikke én-til-én.

Inspirationen til denne artikel kommer i høj grad fra Fjeld (2015), som påpeger kønsskævheder og stereotyper i nordiske ordbøger, heriblandt den ordbog jeg selv har været involveret i, DDO. Eftersom redaktionen i den seneste periode har haft fokus på revidering af artikelbestanden, har resultaterne i Fjeld (2015) været med til at anvise områder hvor ordbogen med fordel kan revideres, og det er især overvejelserne i den forbindelse der præsenteres her. Jeg vil derfor undersøge forholdet mellem korpusser og ordbøger og sammenligne norske og danske forhold. For norsk ser jeg på Leksikografisk bokmålskorpus, LBK, (Knudsen \& Fjeld 2013) og NAOB, som i sin transformation fra NRO til NAOB har gjort brug af LBK, mens det danske materiale beskriver DDO og denne ordbogs underliggende korpus (det redaktionsinterne korpus Bakspejlet i korpusværktøjet CoREST, herefter omtalt som CoREST).

\section{[3] KORPUS SOM ET SPEJL AF SPROGET - IDEAL OG ILLUSION}

En ordbogs forankring $i$ et korpus tjener til at sikre at beskrivelsen ikke begrænses til det sprog som - tilfældigvis - kendes og bruges af redaktørerne selv, men at det beskrevne sprog repræsenteres af en mangfoldighed af genrer og stillejer på tværs af generationer, geografi og sociale grupperinger. Korpusforankringen bliver derved garant for en systematisk og objektiv ordbeskrivelse, noget der i sagens natur er vigtigt for en ordbog der gerne vil forstås og forstår sig selv som videnskabelig.

I tilknytning hertil kan man stille sig to spørgsmål: I hvilken udstrækning giver det overhovedet mening at opfatte korpus som et spejl af sproget? og hvad stiller man op hvis sproget og/eller korpus viser sig at indeholde træk der er modstrid med hvordan vi ønsker os at verden ser ud? 
Udviklingen af korpusser er i høj grad relevant for svaret på det første spørgsmål. I DDO’s periode har beskrivelsesgrundlaget udviklet sig enormt når det gælder kvantitet: Den trykte ordbogs korpus fra midten af 1990'erne var på ca. 40 mio. løbende ord og var statisk (Norling-Christensen \& Asmussen 1998: 225). Tanken var at den trykte DDO skulle være et øjebliksbillede af sproget sådan som det var indfanget i korpusteksterne. Til grund for DDO på nettet ligger i dag et korpus der rummer over 1 milliard løbende ord og desuden er dynamisk. Det vokser måned for måned $\mathrm{i}$ takt med at nye tekster tilføres, og på den måde kan nye ord og sproglig forandring opdages og registreres nærmest mens de finder sted. Prisen for kvantitet og dynamik kommer i form af repræsentativitet. Til den trykte ordbogs korpus blev der gjort meget ud af at indsamle tekster fra en lang række genrer og kanaler; foruden det professionelle sprog fra aviser, fagog skønlitteratur også mere privat sprog i form af breve og dagbøger - samt op imod 20 \% talesprog (jf. Asmussen \& Norling-Christensen 1998: 228). I det moderne korpus udgør journalistiske tekster en uforholdsmæssig stor del på trods af et udbredt ønske om at inkludere flere teksttyper. Korpussammensætningen er ikke resultatet af en beslutning, men en simpel konsekvens af praktiske forhold. Det er ganske enkelt uforholdsmæssigt mere resursekrævende at få løbende adgang til andre teksttyper end journalistiske, især af ophavsretlige grunde.

Det er derfor i dag åbenlyst mere problematisk at anskue korpus som et spejl af sproget, og dermed undermineres naturligvis også en del af ordbogens videnskabelige forankring. Hvis et ord eller en betydning savnes i ordbogen, kan optagelse i ordbogen ikke så let afgøres ved at konsultere forekomsttal i korpus. Det kunne jo tænkes at tilhøre en del af sproget som ikke er tilstrækkelig repræsenteret i korpusteksterne. I sin fulde konsekvens rummer ræsonnementet et alvorligt problem, for derved kan korpusevidens jo altid afvises med at korpus ikke er tilstrækkelig balanceret. Og hvor efterlader det videnskabeligheden?

Det andet spørgsmål ovenfor er principielt uafhængigt af det første, men ikke af den grund enkelt at adskille fra det i praksis. Hvis en ordbog viser en sproglig virkelighed som man er utilfreds med, skyldes det da manglende repræsentativitet i ordbogens beskrivelsesgrundlag, altså i korpus, skyldes det at sproget selv er ufuldkomment og fordomsfuldt, eller skyldes det fordomme hos den eller de redaktører der ved deres udvælgelse og beskrivelse er ansvarlige? Selvom det kan være vanskeligt at sige noget om de tre størrelsers respektive bidrag til eventuelle skævheder, kan det være interessant at sammenligne korpusserne og de ordbogsbeskrivelser der baserer sig på dem. Jeg har derfor udvalgt en række kønsspecifikke ord og set på deres repræsentation i korpusser og ordbøger. 
[4] UNDERSØgELSE AF KORPUSSER OG ORDBØgER

I tabel 1 vises en oversigt over ord der er udvalgt med henblik på at belyse sammenhængen mellem kønsskævheder i ordbøgernes beskrivelser og korpusrepræsentation, jf. oversigten for ordbøger i Fjeld (2015: 44) ${ }^{1}$.

\begin{tabular}{ccccc}
\hline & CoREST & DDO & LB & NAOB \\
\hline han & 6.208 .586 & 12.920 & 878.232 & 27.162 \\
hans & 1.293 .143 & 3.148 & 115.025 & 15.590 \\
ham & 804.153 & 2.044 & 157.109 & 6.858 \\
hun & 2.278 .888 & 7.150 & 486.466 & 14.565 \\
hendes/hennes & 422.456 & 1.061 & 60.931 & $1.371 / 2.449$ \\
hende/henne & 332.338 & 1.551 & 109.979 & $1.850 / 2.336$ \\
mand/mann & 702.736 & 2.368 & 51.762 & $2.742 / 4.118=6860$ \\
kvinde/kvinne & 440.275 & 1.779 & 35.334 & $425 / 3.624=4049$ \\
dreng/gutt & 118.976 & 469 & 11.181 & $80 / 937=1017$ \\
pige/jente & 156.420 & 718 & 12.035 & $187 / 774=961$ \\
\hline
\end{tabular}

TABEL 1: udvalgte ordforekomster i ordbøger og korpusser

På samme måde som det er gjort i Fjeld (2015), kan man få et indtryk af skævheden i resurserne ved at se på kvotienterne for hvert kønnet ordpar, idet kvotienten 1 er udtryk for fuldstændig ligelig repræsentation, mens en kvotient over 1 er udtryk for dominans af hankønsord og en kvotient under 1 for dominans af hunkønsord. For nemheds skyld er formerne han/ham/hans og hun/hende/hendes slået sammen under ét, til han henholdsvis hun, og dreng/pige dækker også over gutt/jente i det norske materiale (og tilsvarende for mann/kvinne). Kvotienterne er sammenfattet i tabel 2.

\begin{tabular}{ccccc}
\hline & CoREST & DDO & LB & NAOB \\
\hline kvotient han/hun & 2,7 & 1,9 & 1,7 & 2,2 \\
kvotient mand/kvinde & 1,6 & 1,3 & 1,5 & 1,7 \\
kvotient dreng/pige & 0,7 & 0,7 & 0,9 & 1,1 \\
\hline
\end{tabular}

TABEL 2: kvotienter for 3 ordpar i korpusser og ordbøger

Kvotienterne giver et omtrentligt billede af kønsskævhederne i materialet, men

[1] Der kan tælles på forskellige måder. For at få sammenlignelige tal har jeg her taget udgangspunkt i NAOB's fritekstfunktion, dvs. optællingerne er strengbaserede. Dog er der søgt på både ubestemt form singularis og pluralis for substantivernes vedkommende og ikke taget hensyn til store og små bogstaver (med de risici for skævheder som det indebærer, fx indgår også forekomster af propriet Hans i søgeresultatet for hans). Da NAOB er baseret på Norsk Riksmålsordbok og derfor rummer et stort antal ældre citater, har jeg for denne ordbogs vedkommende både søgt på gældende bokmålsformer (mann, menn, kvinne, kvinner, hennes) og på ældre riksmålsformer (mand, mæend, kvinde, kvinder, hendes). Optællingen er foretaget $\mathrm{i}$ august 2019 . 
må dog tages med visse forbehold. At mand dominerer for parret MAND/KVINDE kan ikke udelukkende tolkes som en kønsskævhed fordi alene det forhold at mand er et mere polysemt ord end kvinde gør at der må forventes relativt flere forekomster af mand. Eksempelvis dækker en del af forekomsterne betydningen 'mandlig part i et ægteskab', mens den tilsvarende betydning for den kvindelige part ofte er dækket af andre opslagsord end kvinde (fx kone, hustru, viv. Selvom NAOB har registreret denne betydning også for kvinne, er det næppe den mest udbredte betegnelse). Som nævnt i note 1) medfører den strengbaserede søgning desuden at også resultater for propriet Hans er talt med i resultatet for hans.

Uanset disse forbehold er det overordnede indtryk af tallene i de to tabeller klart at de maskuline former dominerer. Eneste undtagelse er DRENG/PIGE (herunder GUTT/JENTE), hvor den feminine form udviser svag dominans i begge resurser for dansk og i korpusmaterialet for norsk. Det er derudover betegnende at skævheden i det danske materiale er større i korpus end i ordbogen, mens det for norsk forholder sig omvendt. En mulig forklaring på det første kunne være at redaktørerne her har været bevidste om kønsproblematikken og derfor stiltiende har rettet en smule op på ubalancen (stiltiende fordi det ikke tidligere var et eksplicit indsatsområde $)^{2}$, mens det sidste vel især lader sig forklare ved at NAOB i udgangspunktet var en historisk ordbog med mange ældre citater og derved $i$ et vist omfang afspejler en tid hvor forholdene mellem kønnene var anderledes. Dette må forventes at slå igennem, også selvom et stort revisionsarbejde har fundet sted.

Ellers er den mest slående forskel i materialet kvotienten HAN/HUN i henholdsvis det danske og norske korpus. Teoretisk set kan forskellen skyldes at de to sprog simpelt hen er forskellige med hensyn til brug af personligt pronomen i tredje person. Men i to så nærtbeslægtede sprog og samfund som det norske og det danske, er det næppe sandsynligt at det er hele, om overhovedet en del af forklaringen. Mere sandsynligt er det at forskellen i de to korpussers sammensætning slår igennem. Her er den mest oplagte forskel at Bokmålskorpus indeholder en større andel af sagprosa og skønlitteratur, mens de journalistiske tekster kun udgør ca. 10 \%. Sidstnævnte er til gengæld overrepræsenteret i CoREST, hvor det udgør den dominerende del, sådan som det ofte er tilfældet med store korpusser på over 1 mia. løbende ord. Det er en interessant tanke hvis et bedre balanceret korpus i sig selv fører til en mere ligelig kønsrepræsentation. Om det virkelig er tilfældet, kræver dog yderligere undersøgelser.

[2] Også denne tolkning må tages med forbehold. DDO’s korpus har ændret sig meget over tid, og sammensætningen af tekster i den trykte ordbogs korpus var væsentlig anderledes end det aktuelle korpus, der domineres af journalistiske tekster, jf. diskussionen nedenfor. 


\section{[5] REVISION AF DDO'S BETYDNINGSBESKRIVELSER}

DDO's redaktion har inden for de senere år fået et stigende antal henvendelser fra brugere som er utilfredse med ordbogens semantiske beskrivelser i en række tilfælde. De opfordrer til at ændre forklaringerne så de bliver mere inkluderende og tidssvarende. Det betyder givetvis noget at mange af DDO's definitioner efterhånden er skrevet for over 20 år siden. Verden har ikke stået stille i den periode, og vi har i dag ikke det samme syn på fx seksuelle minoriteter og kønsrelationer som i 1990'erne - det gælder formentlig også for ordbogsredaktører. Hvad der tidligere var prototypisk, opfattes i dag af mange som stereotypisk - fordi det unødigt ekskluderer mindretalsgrupper der i forvejen har det svært. I redaktionen har vi derfor i den seneste periode især haft fokus på kønsladede ord og udtryk med henblik på at revidere en række ord så de fremtræder mere kønsneutrale.

Lad os se på et eksempel der viser problemet:

ægtepar substantiv intetkøn

par bestående af en mand og en kvinde som er gift med hinanden

FIGUR 4: DDO: udsnit af artiklen cegtepar, før revision

Der er ikke tvivl om at DDO's artikel ægtepar beskriver det der forekommer statistisk mest hyppigt. Ifølge tal fra Danmarks Statistik3 består danske ægtepar i 2019 for 99,7 \%'s vedkommende af en mand og en kvinde, og 98,5\% af de ægteskaber der blev indgået i 2018, var mellem en mand og en kvinde4. Alligevel adskiller NAOB sig på et afgørende punkt fra DDO med følgende forklaring:

ektepar substantiv

par som har inngått ekteskap; gift par

FIGUR 5: NAOB: udsnit af artiklen ektepar

I NAOB's forklaring nævnes ikke kønnet på de personer der indgår ægteskab. Man kan hævde at DDO's forklaring er unødigt specificerende, og at der ingen grund er til at beskrive ægtefolkenes køn når man derved ekskluderer en hel gruppe personer - uanset om det statistisk set er typisk. Omvendt kan man kritisere NAOB for at underspecificere: Kun ved at følge linket til par kan brugeren få at vide at det par der refereres til, består af to personer.

I den reviderede version (november 2019) lyder forklaringen af cegtepar i DDO: “par bestående af to personer som er gift med hinanden". Et andet eksempel på

[3] https://www.dst.dk/da/Statistik/emner/befolkning-og-valg/husstande-familier-boern/familier

[4] https://www.dst.dk/da/Statistik/emner/befolkning-og-valg/vielser-og-skilsmisser/vielser 
før- og efterversioner ses i figurerne $6 \mathrm{a}$ og $6 \mathrm{~b}$.

svigersøn substantiv fælleskøn

mand som er gift med ens datter

FIGUR 6A: DDO: udsnit af artiklen svigersøn (før revision)

svigersøn substantiv fælleskøn

mand som er gift med ens datter eller søn

FIGUR 6B: DDO: udsnit af artiklen svigersøn (efter revision)

Eksemplet i figur 6 viser at den reviderede artikel også dækker situationer med ægtefolk af samme køn, og dette er desuden i artiklen illustreret med et citat.

Eksempler som disse er for så vidt uproblematiske som de uden videre kan ændres, med henvisning til at samfundets love og sprogsamfundets opfattelse har ændret sig. De hører med andre ord til en gruppe ord som det er helt rimeligt at revidere fordi samfundet har ændret sig. Den leksikografiske udfordring ved disse ord består mest $i$ at finde frem til netop de rigtige kandidater og derefter foretage det fornødne.

\section{[6] GRÆNSER FOR INKLUSION?}

Mere problematisk er det hvis brugerne ønsker sig ændringer der ikke er forenelige med beskrivelsesgrundlaget, enten ved at kræve noget fjernet som er veldokumenteret i korpus, eller ved at kræve noget tilføjet som der ikke er sprogligt belæg for. Her bliver man som leksikograf udfordret og kan føle sig splittet mellem videnskabelige principper og personlige værdier.

To henvendelser til DDO's redaktion har haft denne karakter, og begge medførte heftige offentlige debatter om sproget og ordbogens rolle. Den første sag var foranlediget af en opdatering hvor ordet grønloenderstiv blev optaget i DDO. Det blev hurtigt opfanget af danske journalister, og det varede ikke længe før grønlandske brugere tog afstand fra ordet og krævede det fjernet fra ordbogen. Historien fik sit eget liv i Grønland, hvor det af mange blev udlagt som et udslag af dansk racisme. Sagen nåede op på øverste politiske niveau da den grønlandske kulturminister sendte et brev til sin danske kollega hvori hun tog kraftigt afstand fra ordet og optagelsen i ordbogen, som hun kaldte en blåstempling af en racistisk betegnelse ${ }^{5}$.

En lignende debat udspillede sig ved en anden opdatering af ordbogen, hvor det var ordet hudfarvet der kom i centrum. En gruppe brugere på et socialt medie

[5] https://naalakkersuisut.gl/da/Naalakkersuisut/Nyheder/2017/11/161117-Groenlaenderstiv-er-nedladende-og-generaliserende. Se desuden en kritik af DDO's beskrivelse i Farø og Jensen 2018: 219) 
iværksatte en kampagne for at få ændret ordbogens forklaring, og sagen blev grundigt dækket af den danske presse. Det der faldt brugerne for brystet, var at der i DDO kun var angivet forklaringen "af farve som huden hos gruppen af hvide mennesker; meget lys og afdæmpet orange", men ikke betydningen "af samme farve som ens hud". Det anså gruppen som et udtryk for "strukturel racisme"6 og krævede sidstnævite betydningsforklaring tilføjet.

I første omgang førte brugerkravene og presseomtalen ikke til ændringer, med den begrundelse at vi ikke kunne finde nogen entydige belæg for beslutningen i vores korpusgrundlag. Men sagerne gjorde indtryk og påmindede os om vores samfundsrolle og ansvar. Efter ihærdig søgning i kilder uden for ordbogens korpus lykkedes det også at finde nogle eksempler på den nye brug, og det sammenholdt med det faktum at mange korpusbelæg jo ikke lader sig afkode med sikkerhed - førte til at den nye betydning faktisk blev tilføjet ved en opdatering i november 2019. Redaktionsinternt var der ikke fuldstændig enighed om beslutningen. Uenigheden har især drejet sig om hvor meget eller hvor lidt der skal til for at ordbogen fraviger sin korpusforankring: Skal man alligevel tage noget med hvis der (overhovedet) findes belæg på det uden for korpus, eller hvis man selv mener at kende ordet eller betydningen? og kan man omvendt tillade sig at undertrykke ord og betydninger der findes i korpus?

\section{[7] IDEELLE FORDRINGER - I SPROGET OG I ORDBØGERNE}

Hvis der er et redaktionelt ønske om at rette op på en skæv kønsrepræsentation i ordbøgerne, må man først spørge sig hvordan det ideelt set bedst gøres? Bør man ved udvælgelse af citater til ordbogen tilstræbe en ligelig kønsfordeling, fx i fordelingen af ord som de undersøgte HAN/HUN, MAND/KVINDE og DRENG/PIGE, eller bør fordelingen snarere afspejle sproget, dvs. også hvis dette udviser en kønsskævhed, eller korpus? Uden at skrive det eksplicit synes Fjeld (2015) at mene at en ligelig fordeling er det ideelle ${ }^{7}$. Jeg er tilbøjelig til at dele synspunktet, men mest ud fra en antagelse om at fordelingen også er nogenlunde ligelig i sproget. Jeg er dog ikke bekendt med undersøgelser som dokumenterer om dette faktisk er tilfældet - og ved nærmere eftertanke kan jeg godt finde på argumenter for det modsatte. Selvom det er rigtigt at en ordbog er et vindue til den kultur den er lavet i (Fjeld 2015: 40), er en ordbogs opgave først og fremmest at beskrive sproget, ikke samfundet eller kulturen selv. En vigtig pointe i denne sammenhæng er dog at uanset om idealfordringen er beskrivelse af sproget, er det i prak-

[6] https://www.berlingske.dk/kommentarer/den-danske-ordbogs-definition-af-hudfarvet-er-racistisk

[7] Jf. Fjeld (2015): "Kvotienten i Oxford English Dictionary fra 1987 er 3,75 og skiller seg dermed svært negativt ut i forhold til de nordiske ordbøkene" (p. 44). 
sis sproget i korpus der beskrives. Korpus er jo leksikografens praktiske operationalisering af den mere luftige og abstrakte størrelse som et sprog er, og som sådan nødvendig for en systematisk sproglig beskrivelse og dokumentation.

En lignende ideel fordring kan stilles til ordforrådet selv, idet det også rummer vidnesbyrd om kulturelle værdier: Mange erhvervsbetegnelser vidner om en stereotyp opfattelse af kønnenes rollefordeling i arbejdslivet: skraldemand, flyttemand, landmand, husbestyrerinde, loererinde, brodøse, husholderske, syerske. Ud fra et samfundsmæssigt ligestillingsperspektiv kunne de kønsladede ord med fordel erstattes af neutrale betegnelser, men det er næppe ordbøgernes opgave at gøre det så længe de oprindelige ord er i brug i sprogsamfundet. Ordbøgernes rolle er primært dokumenterende og beskrivende.

Det betyder ikke at ordbøgerne skal forholde sig passive og afvente at sprogsamfundet ændrer opfattelse. Redaktionen kan aktivt gøre noget for at være en del af udviklingen ved at sørge for at der i korpus også findes tekster der bruger andre betegnelser og værdier end de traditionelle ( $f x$ tekster om og af forskellige minoritetsgrupper eller kønspolitiske tekster), ved at optage alternative betegnelser og redegøre kontrastivt for forskelle i valør og konnotation mellem ordene og ved målrettet at revidere eksisterende artikler så tidligere tiders stereotype forestillinger ikke får lov at leve videre længere end højst nødvendigt.

\section{[8] KONKRETE REVIDERINGSOPGAVER}

Ud over de eksempler der allerede er nævnt ovenfor, findes der en lang række af ordpar som kan gennemgås med henblik på kontrastiv beskrivelse: kassedame/kasseassistent, tillidsmand/tillidsreprcesentant, husholderske/husholder, sangerinde/sanger, violinistinde/violinist, portnerkone/portner osv. I disse ordpar er det kønsforskellene der er i fokus, men det er nemt at udvide listen med mange andre ord og ordpar fra andre områder: seksuelle og etniske minoriteter, religion, sygdom og andre værdiladede områder: transseksuel/transkønnet, sigøjner/roma, muhammedaner/muslim, mongolisme/Downs syndrom, åndssvag/udviklingshœemmet osv. Det kan ses at problematikken vedrørende kønsskævhed er nært beslægtet med diskussionen af politisk korrekthed. Begge dele handler om at vores normer er under forandring, og det er ikke ligegyldigt hvilke ord vi bruger. Ord fremkalder mentale billeder hos sprogbrugerne, hvilket på den ene side er kommunikativt hensigtsmæssigt fordi vi derved har kognitivt lettere ved at processere dem, men på den anden side er uheldigt hvis billederne er belastede af forældede konnotationer, fordomme og stereotype forestillinger. I den situation overvejer vi i redaktionen om det er nødvendigt at udvide beskrivelsesapparatet hvis det skal være muligt at vejlede ordentligt om sprogbrugen. Det eksisterende inventar af 
sprogbrugsmarkeringer har især gjort brug af "nedsættende" og "uformelt". Betegnelsen "uformelt" er dog hverken tilstrækkelig stærk eller præcis til at dække diskriminerende sprogbrug når markeringen samtidig også bruges om mere hverdagssproglige, talesprogsprægede og ufarlige ord som bcelgmørk, grovcede, hundefryse og hoengerøv. Betegnelsen "nedsættende" er mest velegnet når både afsender og modtager er klar over ordets negative klang: borgerdyr, flceskebjerg, kulturpave og nasserøv er eksempler fra DDO. Men når normer er under forandring, er der ofte netop ikke enighed om ordenes valør, og det bliver da en vigtig opgave for ordbogen at vejlede om ordenes virkning, herunder om de kan virke stødende eller krænkende på modtageren, uanset hvilken intention afsenderen måtte have haft. Det er især vigtigt i forbindelse med brug af ordbogen til produktion. DDO's redaktion har derfor besluttet at indføre betegnelsen "kan virke stødende" for at gøre denne forskel klar. Ved særlig problematiske ord eller ordfelter indføres der også mulighed for en udvidet kommentar hvor redaktørerne kan redegøre for en historisk udvikling (beslægtet med de "stilrutor" som findes i Svensk ordbok, fx ved ordet neger) eller behandle nærtbeslægtede ord sammen og udrede forskelle i betydning og sprogbrug mellem dem.

Et andet indsatsområde er unødigt kønnede opslagsord. De minder om de tidligere nævnte ord med overspecificerende definitioner, men med den forskel at opslagsordet selv indeholder et kønnet ord. I figur 7 vises et eksempel.

narkobaron substantiv, fælleskøn

mand der er kommet til rigdom og magt ved narkohandel i stor stil (ofte nedsættende)

FIGUR 7A: DDO: udsnit af artiklen narkobaron

Baron er som bekendt en titel der kun gives til mænd, og det forhold kan derfor skygge for at bruge sammensætninger med -baron om andet end mænd. Desuden gør de sociale roller i samfundet at virkelighedens narkotikaverden er domineret af mandlige kriminelle (med nogle få undtagelser som Griselda "Queen of Cocain" Blanco), hvorfor beretninger om narkobaroner altovervejende handler om mænd. Alligevel har NAOB valgt en anden løsning:

narkobaron substantiv

NEDSETTENDE person som tjener seg rik på storsalg av narkotika

FIGUR 7B: NAOB: udsnit af artiklen narkobaron

Der er næppe forskel i sproglig evidens mellem norsk og dansk i dette tilfælde, og det mulige alternativ, at optage opslagsordet narkobaronesse, er ikke reelt da det ord slet ikke forekommer i hverken LBK eller i CoREST. Selvom DDO måske er tættere på at beskrive det statistisk mest sandsynlige scenarie, er det ikke 
nødvendigvis den bedste løsning fordi den cementerer en traditionel kønsopfattelse. Det kan være bedre at gøre som NAOB og underspecificere for at lade definitionen være kønsneutral så vidt det er muligt.

På tilsvarende vis kan andre opslagsord med kønnede sidsteled gennemgås, navnlig sammensætninger med -mand. Nogle sammensætninger er symmetriske på den måde at der findes både kvindelige og kønsneutrale pendanter (idrcetsmand, idrcetskvinde, idrcetsudøver; tillidsmand, tillidskvinde, tillidsreprcesentant), og i de tilfælde er en kønnet definition som regel på sin plads. Men der er også sammensætninger der helt savner kvindelige og/eller neutrale modsvarigheder, og her bør man se på om en revision er påkrævet. Det gælder ord som handelsmand, havemand, pistolmand, postmand og pølsemand, ord der alle er defineret med "mand" i definitionen i den nuværende DDO. En eventuel revision kan bestå $\mathrm{i}$ at definere mindre specifikt eller ved at undersøge om en sammensætning med -kvinde eller en neutral betegnelse er berettiget som opslagsord. Det må bero på et skøn i hvert enkelt tilfælde om revision er påkrævet, og hvilken løsning der i givet fald fungerer bedst. Med til revisionen hører naturligvis også et kritisk blik på de valgte eksempelsætninger.

På tilsvarende måde kan ukønnede opslagsord med kønnede definitioner tjekkes for at undersøge om forklaringen er overspecificerende. Det gælder ord som bejler, beundrer, bonde, forfører, frier, hjerteknuser, homo, kleppert, kontormus, mannequin, montør, muskelbundt og tilbeder, der alle i DDO er defineret med formuleringer som "mand" eller "person, især mand" eller tilsvarende med "kvinde". Ofte kan man med fordel bruge en mere kønsneutral formulering og supplere med citater der viser en ikke-stereotyp brug.

I revideringsarbejdet må man heller ikke være blind for egne fordomme. En brugerhenvendelse kan tjene som illustration. Brugeren var utilfreds med DDO's forklaring på voldtcegtsforbryder, der i DDO var defineret som "person (mand) der har begået voldtægt". Umiddelbart kan man synes at brugeren måske var lidt for sart, for det er vel næsten altid mænd der begår voldtægt? Nej, helt så enkel (og for mig var det overraskende) er virkeligheden tilsyneladende ikke. Ifølge en artikel, ganske vist om amerikanske forhold, udgør mænd næsten $40 \%$ af ofrene for sexforbrydelser ${ }^{8}$. Det var også overraskende for mig at der står kvinder bag 70 til $80 \%$ af sexforbrydelser begået mod mænd (i tilfælde hvor overgrebet ikke involverer penetration). Hvis man alene ser på fremstillingen i korpus, er der mindre tvivl. Her er $99 \%$ af de voldtægtsforbrydere der omtales, mænd; kun ganske få eksempler på andet ud af ca. 1000 er det lykkedes mig at finde. Måske er sexforbrydelser mod mænd slet ikke så sjældne, men til gengæld så meget mere

[8] https://www.theatlantic.com/science/archive/2016/11/the-understudied-female-sexual-predator/503492/ 
tabubelagte at de ikke omtales? Resultatet blev i dette tilfælde at artiklen voldtæegtsforbryder nu er revideret så der kun står "person" - i øvrigt i lighed med forklaringen i NAOB.

\section{[9] KONKLUSION}

Køns- og andre skævheder er svære at undgå helt i ordbøger fordi sproget er præget af inerti; ord og udtryk nedarves fra ældre tider, og undertiden bærer de tidligere tiders normer og syn på verden med sig. Talemåder og faste udtryk er kendte eksempler (vcere herre i eget hus, mande sig op, have hår på brystet), men også ordene selv afslører fortidens syn (drengepige og tøsedreng). Ud fra et moderne kønspolitisk perspektiv kan det fx være rimeligt at have et kønsneutralt personligt pronomen, men det betyder ikke at det er nemt at indføre det. I Sverige ser det ud til at være ved at lykkes med hen, men hverken i Danmark eller Norge ser det ud til at være nært forestående. Og sådan er det med mange ord i ordforrådet. Hvorfor har vi kun en havemand eller en garderobedame? Ordene afspejler ældre tiders samfund og rollefordeling, og det tager tid at ændre dem.

Omvendt er der netop grund til at være særlig opmærksom på disse ord så stereotype forestillinger ikke bliver hængende i sproget længere end højst nødvendigt. Redaktionen bør have blik for kønsbalancen og minoritetssprog ved sammensætning af korpustekster, ved lemmaselektion, ved udformning af definitioner og ved udvalg af citater og andre sproglige eksempler. Behandlingen af ideologisk ladede ord har peget på at en udtømmende semantisk beskrivelse næppe er mulig uafhængigt af de værdier der præger det omgivende samfund på et givet tidspunkt. Selv ved tilsyneladende neutrale ord kan der være konnotationer der kræver beskrivelse i form af fx sprogbrugsmarkører eller kollokationer.

Personlig tror jeg at fuldstændig kvantitativ egalitet betyder mindre for ligestillingen end forklaringer og ikke mindst indholdet i eksempelsætningerne. Her bør redaktionen til gengæld skærpe blikket og forsøge at undgå de værste stereotyper. På DDO er arbejdet med det begyndt, ikke mindst takket være Ruth V. Fjelds artikel fra 2015. 


\section{LITTERATUR}

CoREST. https://korpus.dsl.dk/corest, set august 2019.

Den Danske Ordbog. https://ordnet.dk/ddo, set august 2019.

Det Norske Akademis ordbok. https://www.naob.no, set august 2019.

Farø, Ken \& Lene Vinther Jensen. 2018. Den Danske Ordbog på nettet - en undersøgelse af version 3.0. I Sturla Berg-Olsen \& Emma Sköldberg (red.), LexicoNordica 2015 - Fackspråk i nordiska ordböcker. Nordisk förening for lexikografi, 215-232.

Fjeld, Ruth Vatvedt. 2015. Om ordbokseksempler og stereotypisering av kjønn i noen nordiske ordbøker. I Caroline Sandström, Ilse Cantell, Eija-Riitta Grönros, Pirkko Nuolijärvi \& Eivor Sommardahl (red.), Perspektiv på lexikografi, grammatik och språkpolitik $i$ Norden. Helsingfors: Institutet för de inhemska språken, 35-65.

Knudsen, Rune Lain \& Ruth Vatvedt Fjeld. 2013. LBK2013. A Lexicographic Corpus for Norwegian. I Deny A. Kwary, Nur Wulan \& Lilla Musyahda (red.), ASIALEX: Lexicography and Dictionaries in the Information Age, Bali, Indonesia 2022 August 2013, 361-362.

Leksikografisk bokmålskorpus. https://www.hf.uio.no/iln/tjenester/kunnskap/ sprak/korpus/skriftsprakskorpus/lbk/, set august 2019.

Moon, Rosamund. 2014. Meanings, Ideologies, and Learners' Dictionaries. I Andrea Abel, Chiara Vettori \& Natascia Ralli (red.), Proceedings of the XVI EURALEX International Congress: The User in Focus. Bolzano/Bozen: Institute for Specialised Communication and Multilingualism, 85-105.

Nilstun, Carina. 2012. Fra dype betydningshierarkier til flatere struktur - et innblikk i revisjonen av Norsk Riksmålsordbok. I Henrik Lorentzen \& Emma Sköldberg (red.), LexicoNordica 19 2012 - Betydelsebeskrivningar i nordiska ordböcker. Nordisk förening for lexikografi, 123-140.

Norling-Christensen, Ole \& Jørg Asmussen. 1998. The Corpus of The Danish Dictionary. I Lexikos. Afrilex Series 8, 223-242.

Nossem, Eva. 2018. Queering Lexicography - Balancing Power Relations in Dictionaries. I Brian James Baer \& Klaus Kaindl (red.), Queering Translation, Translating the Queer. Theory, Practice, Activism. Routledge, New York, 172-187. 
Russell, Lindsay Rose. 2012. This is What a Dictionary Looks Like: The Lexicographical Contributions of Feminist Dictionaries. I International Journal of Lexicography, 25(1). Oxford University Press, 1-29.

Svensk ordbok utgiven av Svenska Akademien 2009. https://svenska.se, set august 2019.

Trap-Jensen, Lars. 2014. Leksikografisk tradition og fornyelse: tre revolutioner på 100 år? I Ruth Vatvedt Fjeld \& Marit Hovdenak (red.), Nordiske Studier $i$ Leksikografi 12, Rapport fra Konferanse om leksikografi i Norden, Oslo 13.-16. august 2013, 42-68.

KONTAKT

Lars Trap-Jensen

Det Danske Sprog- og Litteraturselskab

ltj@dsl.dk 